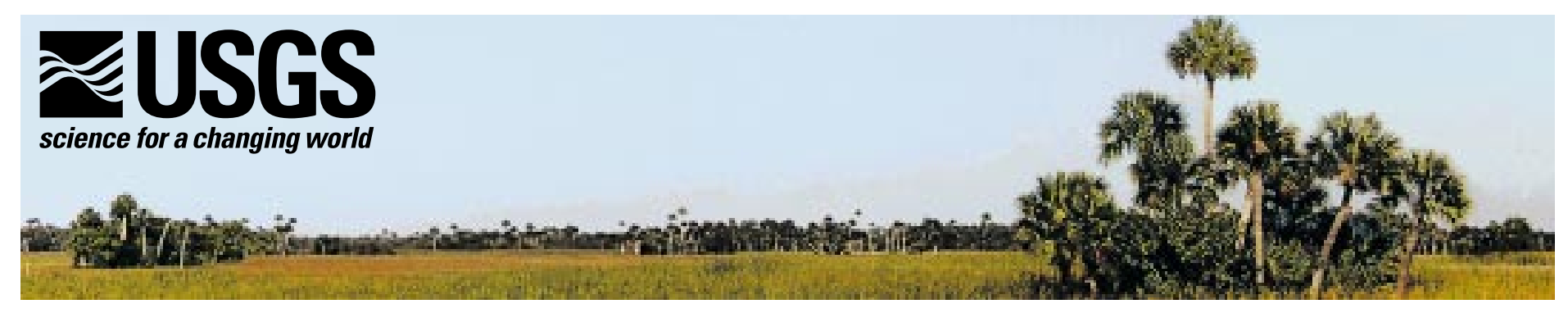

\title{
National Water-Quality Assessment Program: Study Design for Data Collection in the Southern Florida Study Unit, 1996-98
}

\begin{abstract}
A water-quality assessment began in 1994 in southern Florida as part of a national study. The study design for data collection during the intensive phase of the study (1996-98) is described for each of the major components (surface water, ground water, and aquatic biology) used to assess regional water quality. The data will be evaluated to address national, regional, and local water-quality concerns.
\end{abstract}

\section{WHAT IS THE NAWQA PROGRAM?}

In 1991, the U.S. Geological Survey (USGS) initiated a full-scale National Water-Quality Assessment (NAWQA) Program. The three major objectives of the NAWQA Program are to (1) provide a consistent description of current water-quality conditions for a large part of the Nation's water resources, (2) describe how water quality is changing over time, and (3) explain the natural and human factors that may affect observed water-quality conditions.

The NAWQA Program is functionally organized into 59 study units and a National Synthesis Team. The study units represent the diversity of geography, land use, water resources, and water use of the Nation. Intensive assessment activities in each of the study units are conducted on a rotational rather than a continuous basis. Three years of intensive data collection are followed by a 6-year period of reduced data collection. The intensive phase of data collection in the Southern Florida (SOFL) NAWQA study unit began in October 1995 and continued until

September 1998.

\section{WHAT MAKES THE HYDROLOGIC SYSTEM IN SOUTHERN FLORIDA UNIQUE?}

Compared with much of the United States, the hydrologic system of southern Florida is unique in many ways. The land is very flat, and surface waters are either distributed over large wetlands such as the Everglades and the Big Cypress Swamp or are confined in a highly controlled system of canals. Most of the large rivers have been channelized and flows are managed with control structures; the smaller rivers are primarily tidally affected coastal streams. Water moves rapidly between the surface and shallow ground water, depending on water-level gradients, so that the source of the water is difficult to distinguish. Because of the low relief and manipulation of flow, drainage basins are difficult to define.
The hydrologic system is also unique for political reasons. More than 5 million

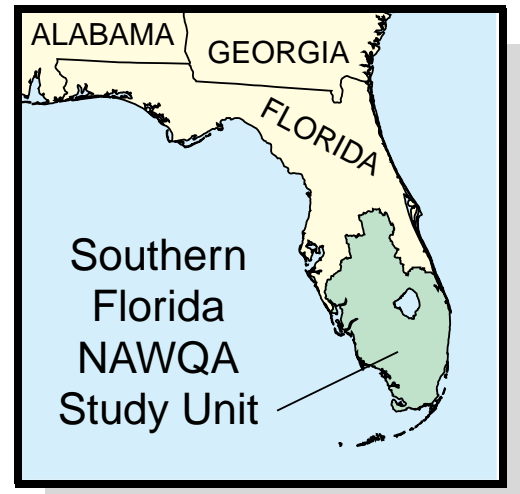
people live along the coast in close proximity to the wilderness wetlands of Everglades National Park, Big Cypress National Preserve, and other public lands. The warm climate that encourages people to live in the region also supports intense agricultural development. Competing interests --- wilderness protection, urban expansion, and agricultural development --- vie for available water resources. In this arena of competing water-resource demands, the largest environmental restoration effort in the world is underway: the protection and restoration of the Florida Everglades.

\section{HOW IS SOFL NAWQA DATA COLLECTION DESIGNED?}

The SOFL NAWQA study unit encompasses about 19,500 square miles. The study unit contains large areas of intensive agricultural development, rangeland, and pasture land; has vast areas of wetlands, mostly in public ownership or under public control; and includes a large urban complex of about 4.5 million people. The natural systems in the study unit have been greatly altered by drainage, development, and water management, and water resources of the region have been significantly degraded.

Data collection is designed to address local, regional, and national water-quality concerns. Major water-quality issues of concern were identified in 1994 through the assistance of a local liaison committee of governmental officials, lay people, and others with an interest in water resources in southern Florida. The most important waterquality issues identified are nutrient enrichment, pesticide contamination, mercury contamination, habitat disturbance, and contamination of the Biscayne aquifer. 
Nutrient enrichment -- Nutrient runoff from agricultural fertilizers, cattle lands, and urban sources adversely affects wetlands in southern Florida. The Everglades ecosystem, which developed and persists only under low-nutrient conditions, is vulnerable to nutrient enrichment,

particularly by phosphorus.

Pesticide contamination -- Agricultural production of sugarcane, citrus, and vegetables involves the use of numerous insecticides, herbicides, and fungicides that subsequently may be transported into surface and ground waters. Urban activities are also a source of pesticides. The geochemical processes controlling the fate and transport of pesticides in water and sediment in southern Florida are not well understood. Moreover, the effects of these compounds on humans and the natural systems of southern Florida are largely unknown.

Mercury contamination -- Mercury has been found at alarmingly high levels in fish and wildlife in southern Florida and poses a threat to the health of wildlife and humans. However, the sources of mercury contamination and its pathways in the food chain are not well understood. habitat disturbance are often most susceptible to invasion by exotic species. Changes in plant and animal community composition have occurred in southern Florida; however, the factors influencing these changes are not well understood.

Contamination of the Biscayne aquifer -- The Biscayne aquifer is the sole source of drinking water for about 3.6 million people living along the southeastern coast of the study unit. Ground water in the aquifer is vulnerable to contamination from surface sources, because high aquifer permeability allows rapid infiltration of surface waters. Contaminants of greatest concern include nitrate, pesticides, and volatile organic compounds.

Each of these water-quality concerns is evaluated with regard to the contribution that the SOFL NAWQA project makes to both regional management needs and national NAWQA Program goals. Collection of data during 199698 to meet these needs and goals is summarized in the following tables for the categories of surface water, ground water, and aquatic biology.

Habitat disturbance -- Dredging, water diversion, and altered hydroperiod can adversely affect aquatic plant and animal communities. Aquatic ecosystems which undergo

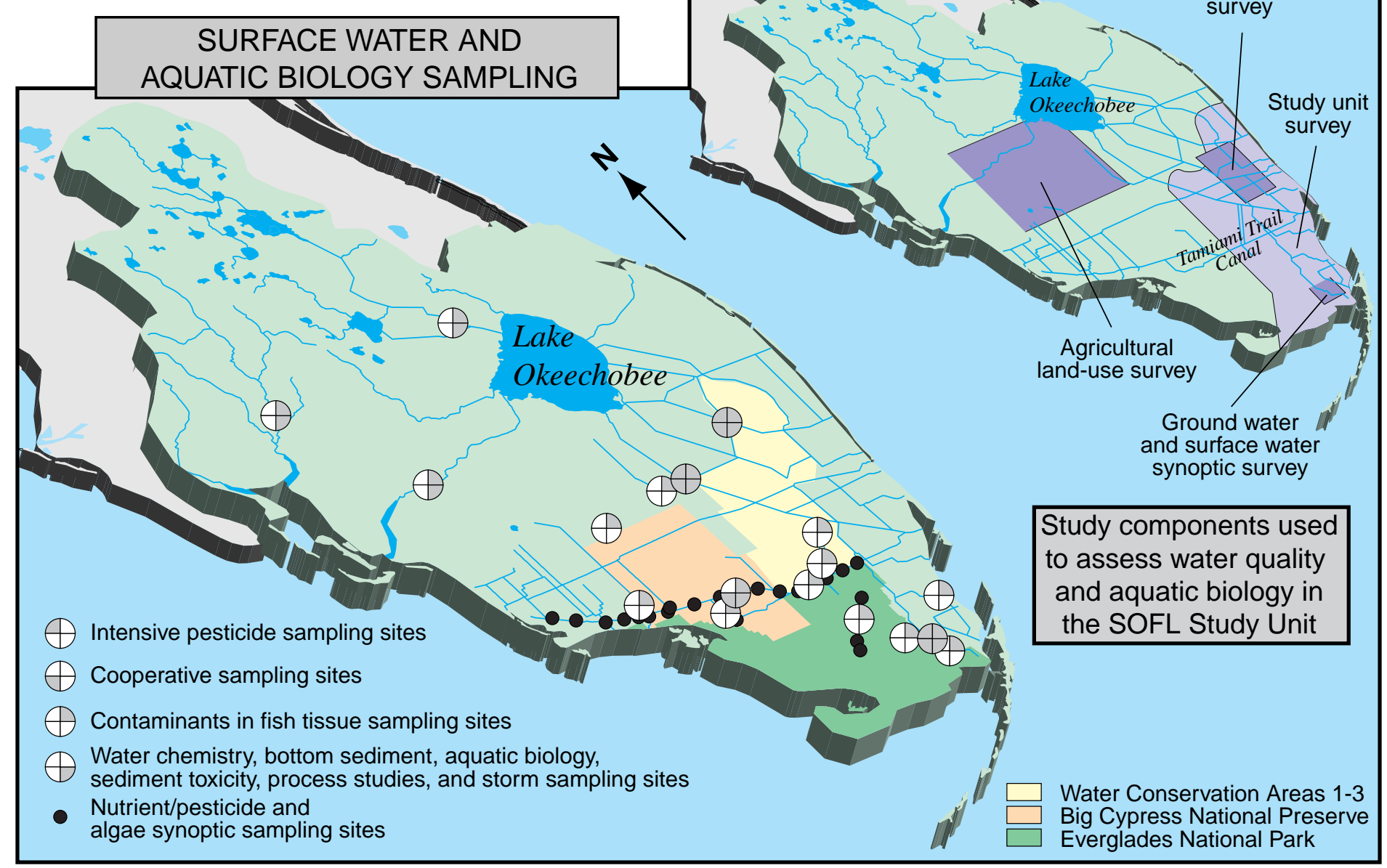




\begin{tabular}{|c|c|c|c|c|c|}
\hline $\begin{array}{l}\text { Study } \\
\text { component }\end{array}$ & Objectives & $\begin{array}{l}\text { Brief description and } \\
\text { water-quality parameters }\end{array}$ & $\begin{array}{l}\text { Number } \\
\text { of sites }\end{array}$ & $\begin{array}{l}\text { Frequency } \\
\text { during } \\
\text { water year }\end{array}$ & $\begin{array}{c}\text { Historical } \\
\text { data } \\
\text { available }\end{array}$ \\
\hline \multicolumn{6}{|c|}{ SURFACE WATER } \\
\hline $\begin{array}{l}\text { Bottom- } \\
\text { sediment } \\
\text { survey }\end{array}$ & $\begin{array}{l}\text { Determine presence of potentially } \\
\text { toxic compounds in sediment at } \\
\text { selected sites }\end{array}$ & $\begin{array}{l}\text { Sample the depositional zone for pesticides, } \\
\text { other synthetic organic compounds, and } \\
\text { trace elements at water-chemistry sites }\end{array}$ & 7 & $\begin{array}{c}1 \\
(1996)\end{array}$ & Some \\
\hline $\begin{array}{l}\text { Water } \\
\text { chemistry } \\
\text { sites }\end{array}$ & $\begin{array}{l}\text { Describe concentrations and loads } \\
\text { of major ions and nutrients at } \\
\text { selected sites }\end{array}$ & $\begin{array}{l}\text { Sample near continuous streamflow sites for } \\
\text { major ions, nutrients, organic carbon, and } \\
\text { suspended sediment }\end{array}$ & 7 & $\begin{array}{c}2-6 \text { in } 1996 \\
12-31 \text { in } 1997 \\
12 \text { in } 1998\end{array}$ & $\begin{array}{c}\text { Data at } \\
\text { some sites }\end{array}$ \\
\hline $\begin{array}{l}\text { Cooperative } \\
\text { sampling } \\
\text { program }\end{array}$ & $\begin{array}{l}\text { Assess the influence of } \\
\text { sampling method and location } \\
\text { on water quality }\end{array}$ & $\begin{array}{l}\text { Sample water-chemistry sites on the same } \\
\text { day as the SFWMD using both USGS } \\
\text { methods and SFWMD methods }\end{array}$ & 5 & $\begin{array}{c}2-6 \text { in } 1996 \\
12-31 \text { in } 1997 \\
12 \text { in } 1998\end{array}$ & None \\
\hline $\begin{array}{l}\text { Storm } \\
\text { sampling }\end{array}$ & $\begin{array}{l}\text { Assess effects of runoff during } \\
\text { high-flow conditions on surface- } \\
\text { water quality }\end{array}$ & $\begin{array}{l}\text { Sample water-chemistry sites during high- } \\
\text { flow conditions for major ions, nutrients, } \\
\text { organic carbon, and suspended sediment }\end{array}$ & Variable & $\begin{array}{l}\text { variable } \\
(1997 \text { and } \\
1998)\end{array}$ & Some \\
\hline $\begin{array}{l}\text { Nutrient/ } \\
\text { pesticide } \\
\text { synoptic } \\
\text { studies }\end{array}$ & $\begin{array}{l}\text { Determine the concentration of } \\
\text { nutrients and pesticides across } \\
\text { southern end of study unit during } \\
\text { high and low flow }\end{array}$ & $\begin{array}{l}\text { Sample sites along the Tamiami Trail Canal } \\
\text { during low flow (June) and high flow } \\
\text { (August) for major ions, mercury, nutrients, } \\
\text { organic carbon, and pesticides }\end{array}$ & 30 & $\begin{array}{c}3 \\
\text { (Aug. 1996) } \\
\text { (June \& Aug. } \\
\text { 1997) }\end{array}$ & Limited \\
\hline $\begin{array}{l}\text { Process } \\
\text { studies }\end{array}$ & $\begin{array}{l}\text { Describe processes controlling the } \\
\text { degradation and biological } \\
\text { availability of pesticides }\end{array}$ & $\begin{array}{l}\text { Deploy and collect semipermeable } \\
\text { membrane devices at selected sites. Collect } \\
\text { water and bottom-sediment samples }\end{array}$ & Variable & $\begin{array}{c}4 \\
(1997-98)\end{array}$ & $\begin{array}{l}\text { Undeter- } \\
\text { mined }\end{array}$ \\
\hline $\begin{array}{l}\text { Intensive } \\
\text { pesticide } \\
\text { sampling }\end{array}$ & $\begin{array}{l}\text { Determine seasonal variation in } \\
\text { the occurrence and concentra- } \\
\text { tions of nutrients and pesticides at } \\
\text { water-chemistry sites }\end{array}$ & $\begin{array}{l}\text { Sample water-chemistry sites which are } \\
\text { located in specified agricultural land-use } \\
\text { areas (citrus, sugarcane, and vegetables) for } \\
\text { nutrients and pesticides }\end{array}$ & 3 & $\begin{array}{c}2 \text { in 1996; } \\
\text { weekly/ } \\
\text { biweekly in } \\
1997 ; \\
\text { monthly in } 1998\end{array}$ & Some \\
\hline \multicolumn{6}{|c|}{ GROUND WATER } \\
\hline $\begin{array}{l}\text { Urban } \\
\text { land-use } \\
\text { survey }\end{array}$ & $\begin{array}{l}\text { Describe water quality in a resi- } \\
\text { dential and light commercial land- } \\
\text { use area in a shallow aquifer sus- } \\
\text { ceptible to contamination }\end{array}$ & $\begin{array}{l}\text { Sample new and existing wells for major } \\
\text { ions, nutrients, organic carbon, pesticides, } \\
\text { radionuclides, trace elements, and volatile } \\
\text { organic compounds (VOCs) }\end{array}$ & 38 wells & $\begin{array}{c}1 \\
(1997)\end{array}$ & Some \\
\hline $\begin{array}{l}\text { Ground water } \\
\text { and surface } \\
\text { water } \\
\text { synoptic } \\
\text { survey }\end{array}$ & $\begin{array}{l}\text { Determine which water-quality } \\
\text { constituents are transported } \\
\text { through shallow ground water } \\
\text { into surface water in an agricul- } \\
\text { tural land-use area }\end{array}$ & $\begin{array}{l}\text { Sample shallow wells and surface-water } \\
\text { sites for major ions, nutrients, pesticides, } \\
\text { and VOCs before and during a surface- } \\
\text { water release in a canal that drains agricul- } \\
\text { tural land }\end{array}$ & $\begin{array}{l}7 \text { wells; } \\
9 \\
\text { surface- } \\
\text { water } \\
\text { sites }\end{array}$ & $\begin{array}{c}1-5 \\
(1998)\end{array}$ & None \\
\hline $\begin{array}{l}\text { Agricultural } \\
\text { land-use } \\
\text { survey }\end{array}$ & $\begin{array}{l}\text { Describe the effects of citrus land } \\
\text { use on water quality in a shallow } \\
\text { aquifer }\end{array}$ & $\begin{array}{l}\text { Sample new wells for major ions, nutrients, } \\
\text { pesticides, radionuclides, and trace } \\
\text { elements }\end{array}$ & 30 wells & $\begin{array}{c}1 \\
(1998)\end{array}$ & Some \\
\hline $\begin{array}{l}\text { Study } \\
\text { unit } \\
\text { survey }\end{array}$ & $\begin{array}{l}\text { Describe overall water quality in } \\
\text { the Biscayne aquifer, which is } \\
\text { used for drinking-water supply }\end{array}$ & $\begin{array}{l}\text { Sample existing wells for major ions, nutri- } \\
\text { ents, organic carbon, pesticides, radionu- } \\
\text { clides, trace elements, and VOCs }\end{array}$ & 30 wells & $\begin{array}{c}1 \\
(1998)\end{array}$ & Some \\
\hline \multicolumn{6}{|c|}{ AQUATIC BIOLOGY } \\
\hline $\begin{array}{l}\text { Contaminants } \\
\text { in fish tissue }\end{array}$ & $\begin{array}{l}\text { Determine the presence of } \\
\text { contaminants that can } \\
\text { accumulate in fish tissue }\end{array}$ & $\begin{array}{l}\text { Collect largemouth bass and Florida gar at a } \\
\text { large number of sites. Sample composites of } \\
\text { whole fish for organic compounds and fish } \\
\text { livers for trace elements }\end{array}$ & 16 & $\begin{array}{c}1 \\
(1996)\end{array}$ & Limited \\
\hline $\begin{array}{l}\text { Sediment } \\
\text { toxicity } \\
\text { testing }\end{array}$ & $\begin{array}{l}\text { Evaluate potential toxicity of bed } \\
\text { sediment at the water-chemistry } \\
\text { sites }\end{array}$ & $\begin{array}{l}\text { Collect bed sediment samples and evaluate } \\
\text { their potential toxicity using ASTM meth- } \\
\text { ods and Hyallela azteca }\end{array}$ & 7 & $\begin{array}{c}1 \\
(1996)\end{array}$ & None \\
\hline $\begin{array}{l}\text { Aquatic } \\
\text { biology }\end{array}$ & $\begin{array}{l}\text { Assess biological communities } \\
\text { and stream habitat at the basic } \\
\text { fixed sites }\end{array}$ & $\begin{array}{l}\text { Quantitatively sample fish, macroinverte- } \\
\text { brates, and algae near water-chemistry sites. } \\
\text { Quantitatively describe stream habitat for } \\
\text { these organisms }\end{array}$ & 7 & $\begin{array}{c}3, \\
1 \text { per year } \\
(1996-98)\end{array}$ & Limited \\
\hline $\begin{array}{l}\text { Algae } \\
\text { synoptic } \\
\text { studies }\end{array}$ & $\begin{array}{l}\text { Determine the influence of nutri- } \\
\text { ents on the algal community along } \\
\text { a nutrient gradient in the southern } \\
\text { part of the basin }\end{array}$ & $\begin{array}{l}\text { Collect algae using artificial substrate sam- } \\
\text { plers at sites across the Tamiami Trail Canal }\end{array}$ & $10-13$ & $\begin{array}{c}3 \\
\text { (June, Aug., } \\
\text { Nov., 1997) }\end{array}$ & None \\
\hline
\end{tabular}




\section{HOW CAN THE NAWQA PROGRAM CONTRIBUTE TO WATER-RESOURCE MANAGEMENT IN SOUTHERN FLORIDA?}

The SOFL NAWQA study is one of many efforts underway to provide scientific information about the southern Florida ecosystem. The need for scientific information stems from a variety of political interests and goals that include the protection and restoration of the Everglades and the southern Florida environment. The State of Florida passed the Everglades Forever Act in 1994, thereby establishing a comprehensive program to restore parts of the remnant Everglades. A coalition of Federal, State, and local agencies and Indian tribes organized under the "South Florida Ecosystem Restoration Task Force" guides restoration.

The Restoration Task Force through its South Florida Working Group includes a Science Coordinating Team which develops the scientific questions that need answers for management decisions regarding restoration. Many agencies and organizations are actively studying and monitoring environmental conditions in the region, including the U.S. Environmental Protection Agency, National Oceanographic and Atmospheric Administration, National Park Service, U.S. Army Corps of Engineers, U.S. Fish and Wildlife Service, South Florida Water Management District (SFWMD), Florida Department of Environmental Protection, Florida Department of Agriculture and Consumer Services, Florida Game and Freshwater Fish Commission, the Miccosukee Tribe of Indians of Florida, the Seminole Tribe of Indians of Florida, the University of Miami, Florida International University, and others. These parties are carrying out studies to meet needs defined by the Task Force and to meet their own programmatic requirements. Some studies are directed at specific restoration activities, such as the SFWMD's Everglades Nutrient Removal Project that evaluates the uptake of phosphorus by marsh- lands. Other activities are more general in nature, such as SFWMD's monitoring of water quality across the region.

The USGS is actively contributing scientific information about southern Florida under three of its programs: the Federal-State Cooperative Program, the Ecosystem Initiative, and the NAWQA Program. Each of these programs complements the others and helps develop a better understanding of the southern Florida environment -- essential for successful restoration. The challenge to the NAWQA Program is to provide useful information that contributes to the restoration of the southern Florida ecosystem, meets USGS programmatic requirements, and does not duplicate ongoing data-collection efforts in the region.

\section{SUGGESTIONS FOR FURTHER READING}

Gerould, Sarah, and Higer, Aaron, 1995, South Florida Ecosystem Program of the U.S. Geological Survey: U.S. Geological Survey Fact Sheet FS-134-95, 2 p.

Gilliom, R.J., Alley, W.M., and Gurtz, M.E., 1995, Design of the National Water-Quality Assessment Program: Occurrence and distribution of water-quality conditions: U.S. Geological Survey Circular 1112, 33 p.

Haag, K.H., Miller, R.L., Bradner, L.A., and McCulloch, D.S., 1996, Water-quality assessment of Southern Florida: An overview of available information on surface- and groundwater quality and ecology: U.S. Geological Survey WaterResources Investigations Report 96-4177, 42 p.

Haag, K.H., and McPherson, B.F., 1997, Organochlorine pesticides and PCBs in southern Florida fishes: Then and now: U.S. Geological Survey Fact Sheet FS-110-97, 4 p.

Marella, R.L., 1998, Water quality assessment of southern Florida--wastewater discharges and agricultural and urban runoff: U.S. Geological Survey Fact Sheet FS-032-98, 6 p.

McPherson, B.F., 1994, National Water-Quality Assessment Program--Southern Florida: U.S. Geological Survey OpenFile Report 94-57, 2 p.

McPherson, B.F., and Halley, Robert, 1997, The South Florida environment ---A region under stress: U.S Geological Survey Circular 1134, 61 p.

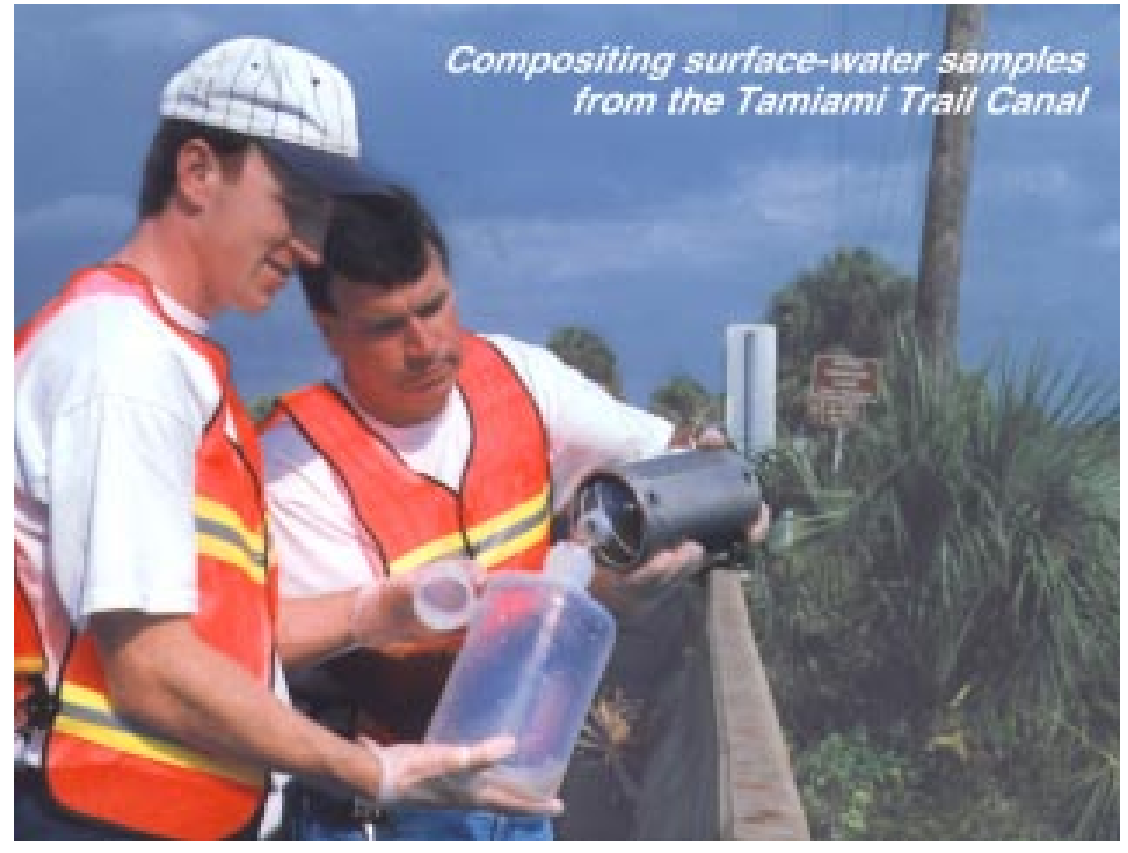

-by K.H. Haag, B.A. Bernard, L.A. Bradner, D.S. McCulloch, B.F. McPherson, and R.L. Miller

Hydrologic data and other information related to the Southern Florida NAWQA project can be obtained from:

Project Chief Southern Florida NAWQA Study U.S. Geological Survey 4710 Eisenhower Blvd. Suite B5 Tampa, FL 33634

http://srv3sfltpa.er.usgs.gov Southern Florida NAWQA 